\title{
The Re-Professionalisation of the Police in England and Wales
}

\author{
Simon Holdaway, Professor of Criminology, Nottingham Trent University
}

\begin{abstract}
In this article contemporary police claims to professional status are analysed and related to a new structure of police regulation in England and Wales. It is argued that the notion of the police as a profession is not new and, unlike police and academic commentary, analysis of this subject, should draw on sociological understandings of professions. The wider policy context within which claims to professionalisation are made is also considered. It is argued that a new, loosely-coupled system of regulation has been developed in England and Wales. Policing's professional body, the College of Policing, is central to this regulatory framework that has placed government at a distance from constabularies and police representative associations. Finally, some of the consequences of the hybrid system are considered and benefits of the framework of analysis proposed are discussed.
\end{abstract}

\section{Introduction}

I suppose you could sum it all up by saying that in Britain certainly, and I have no doubt elsewhere, the time has come when the police are abandoning their artisan status and are achieving by our ever-increasing variety of services, our integrity, our accountability and our dedication to the public good, a status no less admirable than that of the most learned and distinguished professions (Mark, 1977). 
The designation of the police as a profession is not a contemporary idea. During a period when he dealt with serious corruption in his force Robert Mark, Commissioner of the Metropolitan Police, argued that the 1970's was a decade of change from artisan to professional police status. Mark's assertion was by no means the first claim of professional standing for the police. ${ }^{1}$ In his history of English and Welsh constabularies, for example, Crtichley described changes to policing during the 1960s as evidence of their professional standing and a return to fundamental, Peelian principles (Critchley, 1967: 267). Most recently, in his 2011 report about police leadership and training, commissioned and accepted by the Home Secretary as the rationale for the establishment of a professional body for policing in England and Wales, former chief constable Peter Neyroud reiterated police claims to professionalism. He put it that, 'wide-ranging developments over the last two decades secure the police as a profession' (Neyroud, 2011: 45). The establishment of a professional body for the police of England and Wales in 2013 reflects longstanding comment about and assertions that they are a profession. Rather than engaged with novelty, the police of England and Wales are currently reprofessionalising their occupation. ${ }^{2}$

'Re-professionalisation' refers to periodic, authoritative, public claims that the police are a profession. Mark's claim, first made in a 1973 televised lecture, challenged what he regarded as the uncontested corrupt, unethical behaviour of 'professional'

\footnotetext{
1 Michael Banton points out that American police began to debate the idea of the police as a profession in the 1930s and in 1948, Sir John Moylan, past Receiver of the Metropolitan Police, argued that his force was a member of the professions. Banton M. (1964) The Policeman in the Community, London: Tavistock.

2 It is interesting that no police officers have made this point when discussing professionalisation publicly. Most seem to assume that the police are already a profession and then go on to talk about professionalising the service.
} 
criminal lawyers who defended high profile criminals, contrasting it to the ethical practices of police officers (SirRobertMark.co.uk, 1973). When he made this claim he was engaged in a somewhat successful anti-corruption drive within his own constabulary. That is an indicator of how a profession acts.

Later during the same decade, police claims to be a profession focussed more upon the educational qualifications and managerial prowess of senior officers and fast track, direct entrants to officer rank (Holdaway, 1977). These declarations coincided with increasing police collaboration with local and national agencies and an emphasis on skilled management practiced in the public sector. As a profession, the police employed senior officers with similar qualifications and managerial skills.

Peter Neyroud's 2011 report, advocating the establishment of a professional body for the police of England and Wales, emphasised very different professional characteristics, which he traced from the 1980s. He defines the police as a profession akin to medicine, the law and other bodies because they share their classical traits, a code of ethics, accredited qualifications, a foundation of systematic 'scientific' research, and more.

It is now clear that claims to professional status for the police emphasise existing or introduce at different times new occupational characteristics as evidence of professional standing. The meaning of the police as a profession has changed over the years, something the extensive literature about the sociology of the professions 
has long debated more generally (Cain, 1972: ; Evetts, 2011: ; Greenwood, 1957: ; Marshall, 1939: ; Wilensky, 1964). ${ }^{3}$ When the police describe their work routinely as professional in commonsense, everyday language they sustain it with a particular status. The notion of 're-professionalisation', however, captures a different, public declaration in which particular attributes of a profession are emphasised and related, implicitly or explicitly, to the social context within which they articulated. 'Reprofessionalisation' and the contemporary context within which it is manifested are the main subjects of this paper. It is argued that, amongst other matters, a lack of trust in police integrity and new government policies intended to distance ministers from the regulation of constabularies are key aspects of a renewed emphasis on the idea that the police are a profession.

Academics commenting on the police as a profession have not investigated either the meaning of the idea or its social context. They have not questioned police claims through engagement with the extensive sociological literature on the professions, seeming to prefer an implicit acceptance that the police might be and probably are a profession, demonstrating the traditional traits associated with such an institution. . David Sklansky, Jenny Fleming, and Nick Tilley and Gloria Laycock, for example, in recent papers published in a collection to inform 'The Commission on the Future of Policing', considered the professional status of police in the UK and the USA (Fleming, 2014: ; Sklansky, 2014: ; Tilley and Laycock, 2014). Their analyses do not consider definitions of a profession. Neither do they consider why different meanings

\footnotetext{
${ }^{3}$ Bayley DH and Stenning PC. (2016) Governing the Police: Expereince in Six Democracies, London: Transaction Publishers., mention this in a short paragraph but do not analyse its different meanings or, indeed, analyse how professionalisation or any other recent changes are related to the contemporary governance of the police.
} 
of the police as a profession have been fostered at different times; analyse them with reference to the sociology of the professions; or consider how social theory might illuminate their conclusions. Further, professional claims are not located historically or related to wider social and, more particularly, policy change. The notion of the police as a profession has found broad, uncritical acceptance within academe, government and the police.

This paper begins from a distinct analytical standpoint, questioning the taken for granted status of the police as a profession. Contemporary claims to professional status are probed to identify the contexts within which they are made; meanings ascribed to actions establishing the police as a profession are analysed; and the intended and unintended consequences of such meanings and related actions are scrutinized. First, the policy context within which a renewed interest in the police as a profession has developed is discussed. Next, the paper applies insights from the sociology of the professions to the re-professionalisation of the police, to understand professionalisation as processes that invoke particular, authoritative meanings. The paper ends with consideration of re-professionalisation as a key aspect of a new structure of police governance and regulation in England and Wales. ${ }^{4}$ This looselycoupled system is then analysed, the police as a profession being a central to it. As the article progresses, a distinct theoretical perspective on police regulation and its study will be charted.

\footnotetext{
${ }^{4}$ Definitions of regulation are many and varied. In this paper I draw on Scott's definition, 'A set of processes by which norms are established, the behaviour of those subject to the norms monitored or fed back into the regime, and for which there are mechanisms for holding the behaviour of regulated actors within the acceptable limits of the regime Scott C. (2001) Analysing regulatory space: fragmented resources and institutional design. Public Law Summer: 329-353. p.3.
} 
The contemporary developments in police policy analysed here replace a relatively harmonious, institutional structure of police regulation in which the Home Office set or, more recently, agreed constabulary annual plans, articulated Her Majesty's Inspectorate of Constabulary's (HMIC) work and were virtually dependent on ACPO for setting many standards of police practice. Although occasional tensions within and between these actors were evident, formal relationships cohered around a clear, government-led system of police regulation and accountability. The argument here is that the Home Office centred organisation of police regulation has been reformed, replaced by a loosely-coupled system in which the notion of a professional police is vital (Weick, 1976).

Some reforms discussed have distanced central government from local police policy and accountability, suggesting a strategy of 'steering not rowing' (Rhodes, 2000). Importantly, changes related to the emergence of these conditions have drawn on third party, 'independent' recommendations for reform, to some extent distancing further the government from responsibility for both national and local police policies. Accompanying these reforms, significant, direct intervention in the constabularies of England and Wales has also been re-calibrated through the work of HMIC and the Independent Police Complaints Commission (IPCC). These conditions suggest a hybrid, fragmented form of regulatory governance of the police in England and Wales articulated significantly but not exclusively through processes of professionalisation.

\section{The contemporary context of police professsionalisation}

\section{The Neyroud Review}


Neyroud's 2011 review of police leadership and training was commissioned in 2010, very soon after the election of a Conservative government (now in its second term) and is the contemporary reference point for understanding the re-professionalisation of the police in England and Wales. His terms of reference indicate that the Conservative party had been considering radical reforms, including the creation of a professional body and associated policies, during their years in opposition (Neyroud, 2011: 9).

As far as Neyroud was concerned, the immediate problem faced by both police and government was ambiguity about the body responsible and accountable for setting policing standards. Chief constables have operational autonomy within their constabularies but ACPO, their former representative body, had for more than two decades published national guidance to their members. Neither ACPO's proposals for setting policing standards nor their decision-making processes were transparent or accountable publicly (Neyroud, 2011: 66-7). This situation proved difficult for the former National Police Improvement Agency (NPIA) with its brief to identify and disseminate guidance about best police policy and practice. ${ }^{5}$ The Home Secretary wanted clear advice rather than a welter of sometimes discordant information about diverse subjects provided by ACPO and other bodies (Neyroud, 2011: 64). ${ }^{6}$

\footnotetext{
${ }^{5}$ Neyroud was the Head of the NPIA before he retired from the police service and therefore acutely aware of this matter.

${ }^{6}$ ACPO alone had over 200 working groups and sub-groups within what it called ' 13 business areas). In addition, the NPIA, The Association of Police Authorities, The Police Federation and the Superintendents Association, amongst others, also had working groups and other forums to inform policy and practice.
} 
A new, professional body for policing, Neyroud argued, would provide a single source for the definition and dissemination of national police standards, foster greater external scrutiny of proposals for standards, and a great deal more. Its governing body, including 'lay members' and a chair from outside policing, would provide oversight to enhance public accountability of the professional body's work. Importantly, the ability of other groups that previously developed advice about police standards, the Police Superintendent's Association and the Police Federation, for example, would be removed. When established in 2012, The College of Policing was to be the body that 'defined and disseminated core knowledge about 'what works in policing', national policing standards, professional practice and local best practice (Neyroud, 2011: 93-4).

\section{Police ethics and integrity}

The College of Policing's initial work included the publication of a code of ethics for policing. Professional bodies typically publish codes of ethics for their membership and it was no doubt important symbolically for the College to act similarly. Other matters, external to the Home Office and College, however, were also of significance to the initial focus upon ethics as a foundation of professionalisation. Highly publicised incidents questioning police integrity received considerable media and government attention, including cases involving chief officers. The Hillsborough case, for example, saw the integrity of Sir Norman Bettinson, Chief Constable of West Yorkshire Police, called into question. It was alleged that, when working in South Yorkshire Police, Bettinson had overseen the drafting of sanitised statements about the death of 96 and injury to 766 fans at a football match and required officers to sign them. Bettinson retired from his force after considerable public and media 
pressure (Wright, 2015). The manner in which South Yorkshire Police, not least its chief officers, dealt with and investigated the deaths became the subject of a highly critical, independent inquiry and, separately, a formal investigation by the Independent Police Complaints Commission (Hillsborough, 2012). An inquest following the independent inquiry returned a verdict that the 96 fans had been killed unlawfully.

Hillsborough is just one case that brought questions about the reliability of police integrity into public view. The 1993 Stephen Lawrence murder investigation, etched deeply into the contemporary history of troubled police race relations in England and Wales, drew lasting media and public attention (Sir William Macpherson of Cluny, 1999). Other, significant but less high profile cases involving, for example, the chief and deputy chief constables of Cleveland Police, who in 2012 were dismissed from office for gross misconduct, added to government concern (Independent, 2012a: ; Independent, 2013). In North Yorkshire, the chief constable faced disciplinary charges related to nepotism when recruiting staff. His deputy was implicated in the offences and retired (Independent, 2012b). The integrity and managerial competence of chief officers, including the ability of ACPO to foster acceptable ethical standards amongst its membership, was brought to the attention of the government by these and other cases. A code of police ethics written and regulated by a professional police body might influence and better control chief officers' decision-making. 
As far as the lower ranks were concerned, the 2012 'Plebgate' case involving allegations of a fracas between constables on duty outside the prime minister's residence and a Cabinet Minister whom, it was alleged, had sworn at them (Independent, 2014), implicated constables and their representative association, the Police Federation, in allegations of illegal and unethical behaviour made by a cabinet minister and other members of parliament. The House of Commons, Home Affairs Select Committee added their criticisms after questioning Police Federation officials about their action in response to the alleged incident. Questions about public trust in the police tracked Plebgate for several months, drawing attention to the lower police ranks and their representative body, indicating the need for a code of police ethics and a professional body for policing.

\section{Complaints against the police}

The Independent Police Complaints Commission (IPCC), with its mandate to investigate serious public complaints against police officers, has an impact on unethical police conduct but, inevitably, after the event. ${ }^{7}$ Investigation and, possibly, disciplinary action follow a complaint, implying an officer's behaviour should change. A more basic and pervasive measure to prevent misconduct before it occurred was also required and a code of ethics was seen as central to this. Substantial extra funds to restructure and strengthen the IPCC's work were provided by the government in 2014 (House of Commons, 18th Dec. 2013). A code of professional ethics and increased IPCC funding were aspects of a wider project to strengthen the re-professionalisation and regulate police behaviour more effectively.

\footnotetext{
7 The Policing and Crime Bill 2015-16 includes wide-ranging provisions for the revision of the IPCC. They will not, however, have an impact on the points made above.
} 


\section{Localism}

The Tory government has placed a many stranded policy of 'localism' at the centre of its legislative programme. ${ }^{8}$ In this vein, their Police and Crime Commissioner (PCC) policy replaced what they viewed as unelected and unaccountable police authorities with locally-elected Police and Crime Commissioners for every constabulary area. Consultation with local people to determine policing priorities is central to a PCC's work. A PCC appoints the chief constable, removing the screening of candidates by a joint committee of ACPO, The Home Office, Her Majesty's Inspectorate of Constabulary and an 'independent' member who most recently was a retired chief constable. ACPO's influence on chief constable appointments was removed. Even more important is a Commissioner's key work to ensure the chief constable is accountable, delivering their Police Plan based on local citizens' priorities. An intended effect of elected PCCs has been to introduce a new local rather than central government dimension to police accountability.

Teresa May, the Home Secretary who introduced Police and Crime Commissioners, was careful to ensure that the new, local arrangements for police accountability were not dominated by central government. Early in her term of office she told the 2010 Police Federation conference that she was offering the service 'a deal', the essence of which was 'more freedom to the police professionals; more power to the people'

\footnotetext{
8 The notion of 'localism' is not entirely new and this is not the first time it has been of relevance to police policy (McLaughlin E. (2005) Forcing the Issue: New Labour, New Localism and the Democratic Renewal of Police Accountability. The Howard Journal of Criminal Justice 44(5): 473-489.. The change noted is the strengthening of localism within policing, not least by the government's Police and Crime Commissioner policy.
} 
(The Home Office, 2010). Emphasising the idea of officers as members of a profession, her speech stressed that, respectively, chief constables would manage constabularies and locally-based PCCs make them accountable. Freedom from government intervention, as May saw it the opposite of the previous government's police policies, would allow professionals to work to high standards that include their acceptance of the local population setting policing priorities and rendering them accountable through an elected official, the Police and Crime Commissioner, he or she being free from party political interference or bias. The implication was that the Home Secretary works at a distance from local constabularies. She placed the legislation to establish PCCs before parliament and supported in various ways the idea of police officers as members of a profession. That done, local commissioners, with their regulatory powers and other resources, were positioned in the ascendency, free from central government regulation.

\section{Public sector budget cuts}

More than any other feature, stringent cuts to the public sector budget were introduced by The Treasury in 2010 and have remained central to Tory economic policy. To this extent central government has intervened directly in the reform of policing.

In October 2010, central funding for the police service was reduced by $20 \%$ during the four years between March 2011 and March 2015 (Her Majesty's Inspectorate of Constabulary, 2013). This approach was distinct, separating it from the Thatcher government that also made cuts to public expenditure during the 1980 s but placed a 
protective ring-fence around the police. ${ }^{9}$ Clearly, local police budgets have come under pressure and PCCs, who in addition to other responsibilities have a duty to set their constabulary budget, and chief constables, who manage expenditure, have had to make some difficult decisions about the allocation of funds.

$80 \%$ of the police budget is spent on staff salaries and, following the announcement of budgetary cuts, significant changes to pay and conditions were revealed. Certainly, Teresa May, as Home Secretary, did not run away from taking responsibility for new, lower police salaries and pensions. Her action to change them, however, was not based on an internal, civil service analysis of existing policies or her own party's preferences. Rather, an independent review by Tom Winsor, erstwhile railway regulator, set out wide-ranging proposals for the reform of police pay and conditions that were accepted and implemented fully by the Home Secretary (Winsor, 2011).

It is important to note that whilst changes to police pay and conditions have been implemented directly by the Home Office, their justification for reform was based on an independent analysis by Tom Winsor, who worked at a distance from government. There were no doubt discussions between Winsor, ACPO and the Police Federation, the rank-and-file representative body, but he did not enter formal negotiations with them, neither did the Home Secretary when implementing his recommendations. The police were distanced from decision-making about their new terms and conditions and, importantly, an independent person, not the Home

9 In the Autumn Statement, 2015, the Chancellor of the Exchequer announced that the police budget would be protected from further cuts in the immediate future. 
Secretary or the civil service, recommended them to the government. Again, we note the regulation of significant changes to police budgets initiated at a distance from central government.

\section{Her Majesty's Chief Inspector of Constabulary}

In 2012, the Home Secretary appointed Tom Winsor as Her Majesty's Chief Inspector of Constabulary, the first civilian to be appointed to the post. Her Majesty's Inspectorate of Constabulary (HMIC) is one of the most important police regulatory bodies, inspecting and advising constabularies. Its reports provide constabularies, individually and collectively, with instructions about policies and practices found wanting and in need of change within a stated period. With Winsor at the helm and five Inspectors in post, three who are also civilians, the potential influence of chief constables on the Inspectorate has been challenged and weakened. Until 2009 all inspectors were former chief constables. There are now more civilian than police inspectors.

These changes are aspects of the Home Secretary's commitment to create a more independent HMIC (Home Office, 2010). Indeed, Winsor secured extra funding for the Inspectorate, top sliced from forces' financial allocations (HMIC, 2014), and increased the number of inspections of constabularies to six monthly intervals. Plans for national, thematic inspections have been opened to public consultation. The police are just one consultee amongst many. Although it might seem insignificant to an untrained eye, Winsor has worn police uniform at public occasions, symbolising his view that the recruitment of people from non-police posts to senior rank is 
acceptable. The wider framework of police governance includes 'civilians' not just chief constables. HMIC has been distanced further from Home Office and constabulary influence.

\section{The College of Policing}

The College of Policing is the professional body for policing and a major feature of the new police landscape. It has five objectives, including, 'Identifying, developing and promoting ethics, values and standards of integrity', 'identifying, promoting and supporting practice based on evidence' and 'setting standards of professional practice' (College of Policing, 2014). More than this, the College has the ambition for the public to be confident that, 'police officers adhere to a national code of professional policing practice and receive professional development throughout their careers' (College of Policing, 2015b).

A Board of Governors oversees these far reaching objectives and promulgates policies for all areas of police work. The Board is chaired by a former university ViceChancellor, with more 'lay' than police members. A Professional Committee with a membership mostly of chief constables deals with questions about the implementation of policies proposed by the Board. The intention is that the professional committee does not make decisions about appropriate policy but comments on its implementation, no more. It is of course possible and, indeed, may be usual for policy to be changed as it is implemented in constabularies (Holdaway, 1979). In formal terms, however, accountability for appropriate policy implementation lies nationally with HMIC and locally with each PCC. The authorisation of policies for 
the wide range of areas for which the College of Policing has responsibility lies with its governing body.

The College of Policing, unlike the erstwhile ACPO, NPIA or any other police representative association, is central to the Home Secretary's programme of change for constabularies. ${ }^{10}$ Constitutionally, it has responsibility for defining a very widerange of police standards of work and placed at a distance from government as a near autonomous professional body. Once more we find a key actor in the new landscape of policing, a professional body for the police, the College of Policing, distant from the Home Office but undertaking regulatory work of direct relevance to it.

\section{The police as a profession}

The status of the police as a profession is integral to the framework of regulation created by the changes outlined. Indeed, at its 2015 annual conference, the College of Policing's chief executive, Alex Marshall, stated that work completed to establish a body of knowledge about 'what works' in policing, the publication of a code of ethics for the police, a programme of continuous professional development and the licensing and accreditation of officers have secured the police as a classic profession (College of Policing, 2015a).

10 The National Chief Constables Council has replaced ACPO. It has established many committees covering numerous aspects of police work which reflect ACPO's structure. A chief constable takes the lead for each area of 'business', so called. The extent to which the Council will revert to working like ACPO is a moot point. Its objectives, however, are clear, concerned with implementing College of Policing standards and policies. In all areas of work it will work with the College. 


\section{The Sociology of Professionalisation}

Marshall's view chimes clearly with a longstanding sociological approach to the professions based on the definition of characteristics that separate them from occupations (Carr-Saunders and Wilson, 1933: ; Greenwood, 1957). Professions have a professional body; a code of ethics; evidence based practice; accredited employment, for example. This was also the approach accepted by Neyroud, who identified these traits as synonymous with those of the classic professions, law and medicine being two. Definitions of professions were not considered by the academic commentators discussed earlier but it appears they accepted the common-sense 'trait perspective' uncritically (Neyroud, 2012, Fleming, 2014, Tilley and Laycock, 2014)

Criticisms of the trait approach to professions are well established, not the least of which has been the creation and revision of increasingly long lists of traits, their importance sometimes weighted, to include and exclude occupations (Millerson, 1964). The title of Wilensky's influential paper, 'The Professionalisation of Everyone', captured the essence of this criticism (Wilensky, 1964). My main reservation about this analytical approach, however, is that it is static. When compared to a list of professional traits, an occupation either is or is not defined as a profession. The wider social context within which entitlements to professional status are developed is not considered; processes of claims-making are neither described nor analysed; and the meanings of claims of professional standing, some with implicit or explicit regulatory effects, are not taken into account. 
The meanings and effects of claims to professional status, however, are central to Johnson's analysis of professionalisation as a process of constructing an ideology to enhance the authority and power of an occupation (Johnson, 1972). Johnson argued that self-serving interests of authority and power are central to professional status. His analysis challenged Freidson, who argued that professionals' commitment to an ethic of service was consistent with disinterested self-regulation (Freidson, 2001). Johnson's understanding of professions is helpful to an analysis of police professionalisation in the contemporary context described. He directs our attention to forms of authority sought when claims to professionalisation are made in particular contexts.

There is, however, an important feature of the present context of police professionalisation that is in tension with Johnson's analysis. Authority to regulate membership of the police profession and other powers has certainly been given to the College of Policing. Authority and greater, related powers to check and, if needs be, override decisions based exclusively on the authority of police officers as professionals have nevertheless also been given to the College's lay-dominated governing council, HMIC, with its majority of 'lay inspectors', and the Independent Police Complaints Commission. This suggests countervailing opportunities for the police to make claims to self-regulation through professionalisation and a moderation of Johnson's argument. Johnson's approach to professionalisation does not account adequately for these key features of the current re-professionalisation of the police in England and Wales. 
Basing her argument on Foucault's notion of the power of rhetoric, Fournier has argued that 'the disciplinary logic of professionalism' creates the identity of the professional and prompts actions related directly to it (Fournier, 1999). Defined police competencies required for membership of the professional College of Policing, for example, create officers who regard themselves as professionals and act professionally. Again, this perspective has the advantage of directing attention to the ways in which professional status is claimed and practices related to it cloaked with authority. Fournier argues that such claims are fragile and need to be asserted frequently. In this sense, Fournier embraces the notion of re-professionalisation but her fundamental argument proposes the over-determination of identity and related actions that create a professional. We know from research that police identity is not uniform. We also know that a distinction should be made between senior and junior police ranks' ideas about policy and practice and that written policy does not translate into practice straightforwardly (Gundhus, 2012: ; Holdaway, 1983: ; Loftus, 2009).

Julia Evetts has analysed changing processes of professionalisation or, as she calls it, 'professionalism' (Evetts, 2003). In harmony with Becker's and Hughes's perspective of symbolic interactionism (Becker, 1970: ; Hughes, 1958: ; Hughes, 1994), she argues that professionalism is most adequately understood as symbolic processes during which claims for status and authority about occupational values are made by advocates. 'Professionalism', however, is not a wholly symbolic construction. Instrumental changes to action and to the structure of organisations are also fundamental to it. Evetts provides an argument avoiding the crudity of the trait perspective, Johnson's overreach when conceptualising the authority and power 
allowing professionals to regulate themselves, and problems of over-determination presented by Fournier.

Interestingly, Evetts makes a distinction between assertions for 'professionalism from below' and 'professionalism from above' (Evetts, 2011). The former refers to practitioners' claims about their status and authority, more usually concerned with autonomy and aspects of self-regulation. The gains from 'professionalism from above', initiated by senior managerial staff and government, are different, more concerned with standardisation, bureaucracy, assessment, the codification of ethics, continuing education related to a body of professional knowledge, collegial authority, a strong sense of purpose and, crucially, regulation (Muzio and Kirkpatrick, 2011). These are features of police professionalism within the hybrid system of police regulation now established in England and Wales.

\section{Understanding the (re) professionalisation of the police and regulation}

The evidence presented so far suggests that a loosely-coupled structure (Weick, 1976) including a number of new actors has replaced a closely-coupled framework of police regulation in which the government was the central actor. Loose coupling serves as a sensitizing notion that directs research attention away from, 'rationalized, tidy, efficient, coordinated structures.....to some of the attractive and unexpected properties of less rationalized and less tightly related clusters of events (Weick, 1976: 3). The implication is that it is necessary to describe and analyse a web of relationships constructed by events - acts of regulation - that both bring together 
and separate organisations with regulatory authority. As Weick put it, 'coupled events are responsive, but each event also preserves its own identity and some evidence of its physical or logical separateness' (Weick, 1976: 3). One important implication of this perspective for research draws attention to the description and analysis of when, how and what is done by a regulatory actor using their regulatory authority symbolically or instrumentally. It also begs analysis of relationships between actions by one or more actors. They might harmonize or conflict to some extent; they might be discrete. From this perspective it would be inadvisable to understand regulatory actions as if they are irregular, deviations within a more tightly bound system To return to Weick, regulatory activity and systems are not best conceptualised as, 'rationalized, tidy, efficient, coordinated' (Weick, 1976: 3).

In the new framework for police regulation, authority is given to existing and new organisations, HMIC, the IPCC, PCCs and the College of Policing, for example. Each actor is at a distance from government and the Home Office. Each has a formal regulatory objective for distinct areas of policing. PCCs, for example, ensure chief constables implement public priorities for local policing in policy and practice and render chief constables accountable for the management of the force budget. As a professional body, the College of Policing has a duty to establish a corpus of knowledge about what works in policing and ensure that the accreditation of its members includes education about and assessment of their understanding of it. Further, the College has an obligation to ensure that its Code of Ethics pervades police practice, which assumes a regulatory role through the work of chief constables and, indeed, all supervisory officers. HMIC and the IPCC have their own, enhanced areas of regulatory responsibility. Some responsibilities may overlap and be unclear; 
contradictions of who has responsibility for regulating particular areas of policing may be apparent. This, however, does not mean that research should assume loosely coupled regulatory actions are deviations from an ideal of formal rationality that is essential to the notion of a system.

When a PCC questions a chief constable about force performance and requires specific actions to improve policy and or practice, regulatory work very similar to that undertaken by HMIC during an inspection is apparent. As Weick reminds us, each action nevertheless retains its own identity and is distinct. Each intervention is understood appropriately as the contribution of a single actor within a 'looselycoupled system' in which other actors might or might not respond. ${ }^{11}$ Similarly, when the College of Policing sets strategy for an area of policing it is undertaking work that is loosely-coupled to that of a PCC establishing local strategy, based on the views of a constabulary's population. The PCC may give a priority to public rather than 'professional' views expressed by the College. There will also be times when a PCC follows 'what works' and implements advice from the College. In both cases HMIC can inspect and give mandatory, remedial advice to constabularies that do not implement what-works guidance in policy and practice.

As the professional body, the College of Policing is an important actor in this regulatory system. At times the College's professional standing and advice will place them in the ascendency; at other times similar events will not ensure their authority. Crucially, their claim to professional standing and to the police as members of a 11 This is an important difference from mainstream systems analyses. The parts of the system are not adapted deterministically. 
profession affords them status and, more importantly, a regulatory function within the system now created in England and Wales. Professional status does not guarantee authority and power, however. There will be times, for example, when the College of Policing and PCCs take a different view of public priorities and best practice for a constabulary. HMIC might challenge the professional competence of a chief constable and the adequacy of a PCC's regulation of him or her. A straightforward rebuttal by the College or a chief officer, arguing that their professional standing and competence is sufficient to justify their action, would be inadequate. As Evetts (2003) points out, a profession is best understood as constituted by a dynamic process, with claims made to sustain its security as it vies with and yields to the regulatory claims of other actors.

Marianna Valverde's work on 'security' is pertinent to this point, reminding us that the notions of 'a profession', 'professional', 'regulation' and, implicitly, 'system' are vibrant (Valverde, 2011: ; Valverde, 2012). She points out that 'security' is not a normative notion and, following William James's understanding of religion, 'all that we can know about security is what people do in its name and, therefore, our focus should be on practices of governance that appeal to "security" (Valverde, 2011: : 5)'. So it is with the notion of a profession and of regulation. To understand the ways in which the idea of the police as a profession and of claims made on its basis requires the analysis of moments when declarations of professionalism are made and regulatory tasks are undertaken on the basis of its authoritative foundations. This approach reveals the flux and flow of professional and regulatory processes related to the College and, of course, each of the other actors working within the hybrid system described. In particular, and following Valverde's argument, the logic, 
rationale and objectives of professional, regulatory projects; their scope, both temporal and spatial; their claimed jurisdiction to regulate action; and the techniques to translate professional discourses into everyday policing actions, especially through management practices, should be incorporated into analyses of the professionalism of policing.

Valverde also prompts us to consider how her own and Weick's ideas are of relevance to the socio-legal literature about regulation, where one finds notions of 'plural regulation' and 'de-centred regulation' (Black, 2001: ; Black, 2002a: ; Black, 2002b: ; Parker, 2008). These approaches consider to different extents how regulatory functions have involved, 'a shift (and recognition of such a shift) in the locus of the activity of "regulating" from the state to other, multiple, locations, and the adoption on the part of the state of particular strategies of regulation' (Black, 2001: 112). The problem, as Ayres and Braithwaite put it, is now one of enforced regulation beyond state organisations and how to regulate the regulators (Ayres and Braithwaite, 1992).

With Valverde's work in mind, important differences between many approaches to regulation found in the socio-legal literature and that suggested by the argument presented here are apparent. First, much of the relevant literature is concerned with considering possible, effective reforms to regulatory structures suited to new legal and quasi-legal conditions (for example, Braithwaite, 2002, 2013). The approach proposed here, however, is not about required reform of police regulatory structures. It is largely about the development of an analytical perspective to probe the 
contemporary regulation of the police in England and Wales. Secondly, law is frequently given considerable weight as a solution to problems of plural and other diverse forms of regulation. Considering regulation in multi-cultural societies, Christine Parker, for example, seeks to define the conceptual tools to identify a type of emergent, pluralistic law, without or beyond the state...' (Parker, 2008). This ambition is too narrow to consider the wider regulation of law, rules, actions and, as far as police ethics and professionalisation are concerned, sentiments and attitudes. Thirdly, actors within the current police, loosely coupled system of regulation are to some extent autonomous but nevertheless closer to the state than those working within the wide body of organisations considered by analysts of plural and de-centred regulatory bodies.

One relevant insight from the socio-legal literature, however, is the notion of a 'regulatory space', developed by Colin Scott and used metaphorically to analyse different resources available to actors who, draw our attention to the need to conceive of strategies of regulation as consisting of a wide range of negotiated processes, of which rule formation and enforcement are but two (Scott, 2001: p.1)'. Different actors use resources - finance, the ability to shame publicly, information, authority to warn, and to punish, for example - differently at different times. Regulators and regulatees, however, are not restricted to state actors within Scott's argument, which again tends to focus his discussion upon a much wider range of regulators than those within contemporary police arrangements. 
Scott's approach is nevertheless helpful because it identifies the wide range of regulatory resources available to a regulator and argues that regulation is not to be understood as a formally rational, hierarchical system. Rather, it is to be conceptualised as 'complex, dynamic and horizontal' processes that requires an understanding of the limits of law in regulation and the dispersal of authority to act as a regulator' (Scott, 2001:1). Scott goes on to give attention to problems of institutional design that are raised by this situation and to the regulation of the financial sector. They are not the concern of this article but the way in which Scott frames research about regulation is certainly of relevance.

\section{Discussion}

The analytical approach outlined so far has considerable implications for research. Meanings of the police as a profession and of related regulatory organisations are placed within their policy and wider social contexts; opportunities to describe and analyse relationships between those meanings and actions become possible. The parsing of claims and counter-claims made by actors can be analysed. Disputes about which actor has authority to regulate particular aspects of policing reveal the flux and flow of regulatory jurisdictions, techniques and claims based on professional and other competences. The social topography of what might seem like a discrete set of regulatory organisations can be charted. These features distinguish the approach advocated from existing criminological accounts of the police as a profession. 
The notion of a loosely-coupled system sensitises us to these and related data about professionalism and regulation. It abandons the notion of an implicit, formally rational structure lying behind apparent fragmentation. Research about regulatory systems is not adequate if it compares loosely-coupled structures to an implied ideal, normative, closely coupled system. Each organisation within a loosely-coupled regulatory system has formal purposes and functions. People working within them act discretely and, to different extents, in relationship with colleagues and with employees in associated organisations (Bittner, 1967). Regulatory systems are constructed and sustained continually by their action. The apparent fragmentation of loosely-coupled systems does not mean that they are inherently unstable, wholly unpredictable or dysfunctional. Valverde's understanding of security, Evett's notion of professionalism and Weick's consideration of loose-coupling help us to keep in mind that, as quoted earlier, 'coupled events are responsive, but each event also preserves its own identity and some evidence of its physical or logical separateness' (Weick, 1976: 3).

The contemporary notion of police professionalism analysed suggests that the longstanding argument that written policy and law are to be distinguished from law and policy in action is pertinent to understanding the police as a profession (Pound, 1910). To compare characteristics of the police in England and Wales to a list of professional traits could be an indicative starting point for research but the sociology of the professions warns convincingly that the analytic strength of the trait approach is weak. Importantly, Johnson's argument that professional status masks an ideology of freedom for professional bodies to regulate autonomously with greater authority and power draws our attention to the relationship between professionals 
and regulation. It needs considerable tempering in the current context of policing, however. Checks and balances to autonomous regulation by police professionals have been identified.

There will be times when police make authoritative judgements on the basis of their authority as professionals. An implication of the theoretical argument presented implies, however, that professionalism is accomplished rather than a realist, descriptive category. Research needs to give attention to strategies and tactics police use to promote it as a taken-for-granted phenomenon. The ways in which it is framed - promoted, expressed, communicated, acted-out and parsed through discourse, performances and symbolic action - can be described and analysed (Brubaker et al., 2004).

The foundations of ambitious research about professionalism and regulation within a loosely-coupled system have been set out. Some caution about the efficacy of 'loose structure' as a key concept should nevertheless be expressed. A point, made by Weick himself, is the need to demonstrate precisely how loose parts of a regulatory system relate to each other, the consequences of their relationships, and the contexts within which the parts are more or less aligned. Without that stipulation any assemblage of structure can be conceptualised as 'loosely-coupled' and become an analytical catch-all rather than a sensitising concept drawing attention to relationships and meanings. 
The final point is obvious but one too often absent from contemporary research about the police: the social world does not describe itself through the re-presentation of qualitative or quantitative research data (Atkinson, 2015). This is why a central feature of the analysis presented draws on theoretical work about professions and about regulation. A theoretical architecture of structure determining social life has no place within it. The central concern is the (often small) ideas and related actions that construct and sustain a regulatory system, and the notion of the police as a profession.

\section{Conclusion}

Police claims to professional status are recurring, not new. It has been established that, once situated within their social context and viewed through a theoretical lens, the re-professionalisation of the police is understood as a central facet of a new, hybrid, loosely-coupled system of police regulation.

The current professionalisation of the police is a key feature of wider changes distancing the Home Office from the regulation of constabularies. The College of Policing, the police professional body, has central regulatory functions developed alongside other important changes in the organisation of police regulation.

The notion of loose-coupling sensitises us to a novel research perspective on police regulation in England and Wales. Drawing on appropriate theoretical arguments, it becomes possible to document empirically how and within which contexts the 
regulatory functions of each agency vie with and yield to each other. Authoritative claims to an area of jurisdiction and related actions that may cut across the work of other regulatory agencies can be examined. A new, dynamic landscape of police regulation affording a central place to professionalism can be described and analysed. 


\section{Bibliography}

Atkinson P. (2015) Rescuing Interactionism from Qualitative Research. 38(4): 467474.

Ayres I and Braithwaite J. (1992) Responsive Regulation: Transcending the Deregulation Debate, Oxford: Oxford University Press.

Banton M. (1964) The Policeman in the Community, London: Tavistock.

Bayley DH and Stenning PC. (2016) Governing the Police: Expereince in Six Democracies, London: Transaction Publishers.

Becker HS. (1970) Sociological Work, Chicago: Aldine.

Bittner E. (1967) The concept of organisation. Social Research 32((Winter)): 699715.

Black J. (2001) Decentring Regulation: Understanding the Role of Regulation and Self-Regulation in a â€ Post-Regulatoryâ $€^{\mathrm{TM}}$ World. Current Legal Problems 54(1): 103-146.

Black J. (2002a) Critical Reflections on Regulation. Australian Journal of Legal Philosophy 27: 1-35.

Black J. (2002b) Regulatory Conversations. Journal of Law and Society 29(1): 163196.

Brubaker R, Loveman M and Stamov P. (2004) Ethnicity as cognition. Theory and Society 33: 31-64.

Cain M. (1972) Police Professionalism: Its Meanhing and Consequences. AngloAmerican Law Review 1: 217-231.

Carr-Saunders AM and Wilson PA. (1933) The Professions, Oxford: Clarendon Press.

College of Policing. (2014) Five Year Strategy, Coventry: College of Policing.

College of Policing. (2015a) College of Policing Annual Conference. Available at: http://www.college.police.uk/News/College-events/Pages/College-of-PolicingAnnual-Conference-2015.aspx.

College of Policing. (2015b) Interity in Policing. Available at: http://www.college.police.uk/What-we-do/Ethics/integrity-inpolicing/Pages/Integrity-in-policing.aspx.

Critchley T. (1967) A History of the Police in England and Wales, London: Constable.

Evetts J. (2003) The Sociological Analysis of Professionalism: Occupational Change in the Modern World. International Sociology 18(2): 395-415.

Evetts J. (2011) The new professionalism? Cahllenges and opportunities. Current Sociology 59((4)): 406-422.

Fleming J. (2014) The pursuit of professionalism: lessons from Australia. In: Brown JM (ed) The Future of Policing. Oxford: Routledge, 355-368.

Fournier V. (1999) The Appeal to 'Professionalism' as a Disciplinary Mechanism. The Sociological Review 47(2): 280-307.

Freidson E. (2001) Professionalism, the Third Logic: On the Practice of Knowledge: University of Chicago Press.

Greenwood E. (1957) Attributes of a profession. SOcial Work 2: 44-55.

Gundhus H, I. (2012) Experience or Knowledge? Perspectives on New Knowledge Regimes and Control of Police Professionalism. Policing 7(2): 178-194. 
Her Majesty's Inspectorate of Constabulary. (2013) Policing in Austerity: Rising to the Challenge, London: Her Majesty's Inspectorate of Constabulary.

Hillsborough IP. (2012) Hillsborough: The Report of the Independent Panel. Available at: http://hillsborough.independent.gov.uk/repository/report/HIP report.pdf.

HMIC. (2014) HMIC Inspection Programme 2014/15. London: Her Majesties Inspector of Constabulary.

Holdaway S. (1977) Changes in Urban Policing. British Journal of Sociology 28((2)): 119-137.

Holdaway S. (1979) Police-Black Relations: the Professional Solution. In: Holdaway $\mathrm{S}$ (ed) The British Police. London: Edward Arnold, 66-82.

Holdaway S. (1983) Inside the British Police: A Force at Work, Oxford: Blackwell.

Home Office. (2010) Policing in the 21st Century: Reconnecting police and the people London: Home Office.

House of Commons. (18th Dec. 2013) Column 112WS: House of Commons.

Hughes EC. (1958) Men and Their Work, Glencoe: The Free Press.

Hughes EC. (1994) On Work, Race and the Sociological Imagination, London: University of Chcago Press.

Independent PCC. (2012a) Cleveland Police Deputy Chief Constable dismissed following IPCC managed investigation. Available at: https://www.ipcc.gov.uk/news/cleveland-police-deputy-chief-constabledismissed-following-ipcc-managed-investigation.

Independent PCC. (2012b) Recruitment campaign - North Yorkshire Police. Available at: $\quad$ https://www.ipcc.gov.uk/investigations/recruitment-campaign-northyorkshire-police-0.

Independent PCC. (2013) Cleveland Police Chief Constable Sean Price dismissed following investigationf. Available at: https://www.ipcc.gov.uk/news/cleveland-police-chief-constable-sean-pricedismissed-following-ipcc-investigation.

Independent PCC. (2014) Andrew Mitchell - Metropolitan Police Service, West Midlands Police, West Mercia Police and Warwickshire Police. Available at: https://www.ipcc.gov.uk/investigations/andrew-mitchell-metropolitan-policeservice-west-midlands-police-west-mercia-police.

Johnson TJ. (1972) Professions and power, London: Macmillan.

Loftus B. (2009) Police Culture in a Changing World, Oxford: OUP.

Mark R. (1977) Policing a perplexed society, London: George, Allen and Unwin.

Marshall TH. (1939) The recent history of professionalism in relation to the social structure and policy. Canadian Journal of Economics and Political Science 5: 325-340.

McLaughlin E. (2005) Forcing the Issue: New Labour, New Localism and the Democratic Renewal of Police Accountability. The Howard Journal of Criminal Justice 44(5): 473-489.

Millerson G. (1964) The qualifying associations, London: Routledge and Kegan Paul.

Muzio D and Kirkpatrick I. (2011) Introduction: Professions and organizations - a conceptual framework. Current Sociology 59(4): 389-405.

Neyroud P. (2011) Review of Police Leadership and Training. London.

Parker C. (2008) The Pluralization of Regulation. Theoretical Enquiries in Law 9(2): 349-369.

Pound R. (1910) Law in Books and Law in Action. American Law Review 44: 12-36.

Rhodes RAW. (2000) The governance narrative: key findings and lessons from the ESRC's Whithall Programme. Public Administration 78(2): 345-364. 
Scott C. (2001) Analysing regulatory space: fragmented resources and institutional design. Public Law Summer: 329-353.

Sir William Macpherson of Cluny. (1999) The Stephen Lawrence Inquiry: Report of an Inquiry by Sir William Macpherson of Cluny,, London: HMSO.

SirRobertMark.co.uk. (1973) 'Minority Verdoct' The Dimbleby Lecture 1973. Available at: http://tinyurl.com/zeh2pqt.

Sklansky DA. (2014) The Promise and Perils of Police Professionalism. In: Brown J (ed) The Future of Policing. London: Rountledge.

The Home Office. (2010) Police reform: Theresa May's speech to the Police Federation. Available at: https://www.gov.uk/government/speeches/policereform-theresa-mays-speech-to-the-police-federation.

Tilley $\mathrm{N}$ and Laycock $\mathrm{G}$. (2014) The police as profesional problem solvers. In: Brown JM (ed) The Future of Policing. Oxford: Routledge.

Valverde M. (2011) Questions of security: A framework for research. Theoretical Criminology 15(1): 3-22.

Valverde M. (2012) Analyzing punishment: Scope and scale. Theoretical Criminology 16(2): 245-253.

Weick K. (1976) Educational Organisations as Loosely Coupled Systems. Administrative Science Quarterly 21(1): 1 - 12.

Wilensky H. (1964) The professionalization of everyone? American Journal of Sociology 70: 137-158.

Winsor T. (2011) Independent Review of Police Oficer and Staff Remuneration and Conditions, London: H.M. Government.

Wright S. (2015) Hillsborough police chief keeps $£ 1 m$ pension and escapes misconduct charges because he retired last year. Available at: http://www.dailymail.co.uk/news/article-2300437/Hillsborough-police-chief-SirNorman-Bettison-keeps-1m-pension-escapes-misconduct-charges.html. 